\title{
The Implementation of Bandung Smart City to Improving the Welfare of its Citizens
}

\author{
Idil Akbar $^{1 \mathrm{a}}$, Budi Sutrisno ${ }^{2}$ \\ ${ }^{1}$ Government Science Department, University of Padjadjaran, Bandung, Indonesia \\ ${ }^{2}$ Sociology Department, University of Padjadjaran, Bandung, Indonesia \\ ${ }^{a}$ Corresponding author: idil.akbar@unpad.ac.id
}

\begin{abstract}
This research aims to identify and perform critical analysis of implementation the concept of the Smart City based on 6 large indicator namely Smart People, Smart Economy, Smart Environment, Smart Government, Smart Living and Smart Mobility. While the special targets to be achieved is mapped institutions and actors in the dialectic of the implementation of the Smart City follows the interaction with its cultural and social environment which then increase the welfare of the citizens. The study was conducted on the Government of the city of Bandung which in recent years has been implementing the concept of smart city in the management of the continent. Therefore, this research carried out to obtain a comprehensive description and analyses how far the city of Bandung realize the concept of Smart City based on the indicators above. Research was done using qualitative methods analytically, with deep and comprehensive analysis of the object that is examined and perform analysis of the facts and the data obtained. Data collection is done by observation, in-depth interviews and literature study. The concept of Smart City closely related with the use of information technology (ICTs) as medium broker with government citizens and disciplinary strategy citizen of the city. In addition human aspects also become very important because the final destination of Smart City is to improve the welfare of the citizens of the city. Therefore the existence of Smart City should be able to increase the active participation of the citizens in the various development program (active citizen).
\end{abstract}

Keywords-smart city, citizen's welfare, government, bandung city, ICTs

\section{INTRODUCTION}

Based on survey IKCI 2015, Bandung is one of 15 cities from 93 autonomous cities that categorized as smart city with Depok, Bandung, Semarang, Surabaya, and Tangerang with as large city. For the middle category city is the Balikpapan, Pontianak, Yogyakarta, Malang, and Surakarta (Solo). While for a group of the small town of Madiun, Malang, Mojokerto, Bontang and Salatiga [1].

Smart City has six main indicator that must be implemented that is: Smart Economy, Smart Mobility, Smart Government, Smart Environment, Smart Living and Smart People [2]. Based on the results of the study of literature, the concept of Smart City closely related with the use of information technology (ICTs) as medium broker with government citizens and disciplinary strategy citizen of the city. Final destination of Smart City is to improve the welfare of the citizens of the city.
Therefore the existence of Smart City should be able to increase the active participation of the citizens in the various development program (active citizen)

Based on the phenomenon and the context of the research that has been presented so we are interested to examine how far the participation of the citizens of Bandung to realize the concept of Smart City based on the indicator Smart Economy, Smart Mobility, Smart Government, Smart Environment, Smart Living and Smart People; and how the concept of Smart City applied to the government of the city of Bandung formed social discipline citizens of Bandung in social life both in the specific places and public.

\section{RESEARCH METHOD}

The research using qualitative approach to produce an indepth explanation about the words, writing and behavior that can be observed from an individual community groups and organizations in a specific context is examined from the point of view of the apples, comprehensive and holistic approach. For the purpose of this research, researchers choose to use the type of descriptive research analytically so that the main steps a research which is a description of the research object can be formulated by making it easier for the next step is to do a deep and comprehensive analysis of the object that it is not intended to test the hypothesis, but only describe what it is about the variables, symptoms or the situation and perform the analysis of the facts of the foundation for the guidelines in the future.

The data collected through observation, in-depth interviews, and study of the library. The data is then analyzed used analytical technique or with data processing through the four stages, namely with critical against data, data reduction, classification data and perform the interpretation [3]. While the validity test and reliability of the data is done by the method of triangulation data.

\section{RESULT AND DISCUSSION}

\section{A. The profiles and principles of Bandung as smart city}

Bandung Smart City can be defined as the city of Bandung built and developed and managed by using Information and Communication Technology (ICT) to connect the monitor and control various existing resources more effectively and efficiently to maximize services to citizens as well as to 
support the development of sustainable development [4]. Related to the development of Bandung smart city is part of the vision and mission of the Mayor of Bandung that later will be reached Bandung as a city of MARTABAT (slogan of Bandung city).

Based on a master plan of Bandung smart city (2013), the architecture design of smart city development in Bandung city is made in general and also for each of the components. There are ten architectural design in the development of smart city in the city of Bandung [5], among others : 1) Governance (Smart Government-income, licensing and assets); 2) Education (Smart Education); 3) Transportation (Smart Transportation, Smart Parking); 4) health (Smart Health); 5) Energy (Smart Grid/Smart Energy); 6) Security (Smart Surveillance); 7) Environment (Smart Environment); 8) Society/Social (Smart Society, Smart Reporting, Smart Passport); 9) financial (Smart Payment); 10) Trade (Smart Commerce).

\section{FIGURE 1. ARCHITECTURE SERVICES OF BANDUNG SMART CITY}

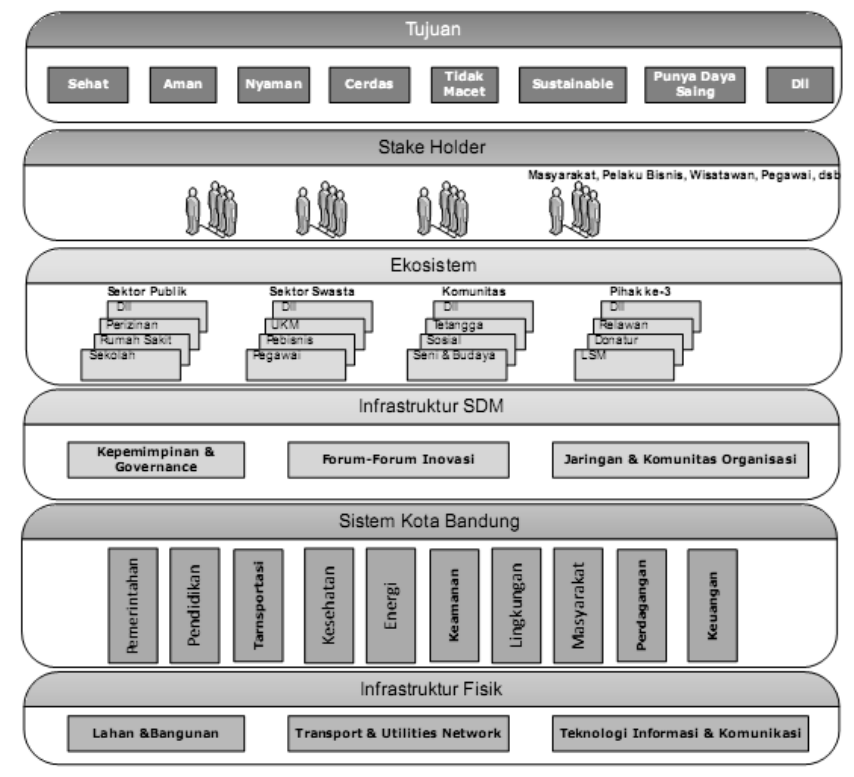

Ten parts is more specific when compared with the six dimensions of the city of smartphone. But when categorized and its components including into six general dimension in the smart city.

In implementing smart city required principles that animate every development and its utilization. The principles that applied in the implementation of Bandung city Smartphone (Smart City), among others: 1) support and realize Bandung BERMARTABAT; 2) to encourage and support the development of human resources Bandung city; 3) the development of Bandung city is done with the concept of sustainable development; 4) resource usage of Bandung city with effective and efficient; 5) Increase the services to the citizens of the city; 6) increase the performance of Bandung city government better with effective systems, efficient, accountable and transparent; 7. promote the role of the stakeholders in the city of Bandung in realizing the city of Bandung BERMARTABAT; 8) equitable growth and the results of the development of the city of Bandung; 9. Promote and improve the quality of life of the citizens of the city; and 10) ICT built an integrated and in accordance with the needs.

The goals of the implementation of the Smart City in the city of Bandung so Bandung became a city that smart is that the city of Bandung be healthy, comfortable occupied, easy to get education, secure, not crunch, have competitiveness and sustainable development (sustainable). The following is the purpose of the implementation of the various services in Bandung smart city.

\section{TABLE 1. SERVICES AND GOALS OF BANDUNG SMART CITY}

\begin{tabular}{|c|c|}
\hline Services & Goals \\
\hline $\begin{array}{l}\text { Smart } \\
\text { Government }\end{array}$ & $\begin{array}{l}\text { Improve the performance of the government that } \\
\text { effective, efficient, accountable and transparent in } \\
\text { an effort to increase the capacity of services } \\
\text { metropolitan city. }\end{array}$ \\
\hline Smart Education & $\begin{array}{l}\text { Develop human resources be health, smart, moral, } \\
\text { professional and competitive. }\end{array}$ \\
\hline $\begin{array}{l}\text { Smart } \\
\text { Transportation }\end{array}$ & $\begin{array}{l}\text { Provides a secure transportation system, efficient, } \\
\text { comfortable, affordable and environmentally } \\
\text { friendly. }\end{array}$ \\
\hline Smart Health & Help realize Bandung healthy. \\
\hline Smart Energy & $\begin{array}{l}\text { Realize Bandung as a city that is energy efficient } \\
\text { and independent. }\end{array}$ \\
\hline Smart Surveillance & $\begin{array}{l}\text { Observation and environment resources the city to } \\
\text { raise awareness of security and the handling of the } \\
\text { citizens. }\end{array}$ \\
\hline $\begin{array}{l}\text { Smart } \\
\text { Environment }\end{array}$ & $\begin{array}{l}\text { Managing of Bandung city toward an integrated } \\
\text { metropolitan environmentally. }\end{array}$ \\
\hline Smart Social & $\begin{array}{l}\text { Increase the sensitivity and concern of the public } \\
\text { toward social environment. }\end{array}$ \\
\hline $\begin{array}{l}\text { Smart Payment \& } \\
\text { Identity }\end{array}$ & $\begin{array}{l}\text { Realizing the financial system and the identity of } \\
\text { themselves in the city which is transparent, } \\
\text { accountable and effective. }\end{array}$ \\
\hline Smart Commerce & $\begin{array}{l}\text { Develop the economy city competitiveness in } \\
\text { supporting the creation of jobs and public services } \\
\text { and enhance the role of the private sector in the } \\
\text { economic development of the city. }\end{array}$ \\
\hline
\end{tabular}

Source: from Final report grand design Bandung smart city

\section{B. Bandung smart city roadmap}

Based on a grand design is then drafted the road map of Smart City in the city of Bandung inside includes 5 (five) strategic plans, such as:

a. The development of the infrastructure of the stanchion operation of government programs and activities such as public buildings Bandung Command Center (BCC), providing $\mathrm{Wi}-\mathrm{Fi}$ in public areas and others.

b. Capacity building is the process of improving the ability, skills the attitudes and behavior of human resources both in the government of the city and related parties especially in the use of ICT in public service.

c. Open and smart government that is holding the government which is transparent and closer to the public 
by integrating information and communication technology in meeting of public services.

d. Citizen engagement is a society of awareness and responsibility to the performance of the government and participate and provide input in the form of knowledge, active contribution and also participate in social troubleshooting business in society.

e. Bandung Techno polis thoughts of the area of the new growth center and modern concept one stop living covers the business, the workplace, the place of learning and leisure integrated in one region based on the global ICT.

Now the roadmap is then lowered to various work program of concrete steps that will be carried out by the government in a period of 5 years. Work Program including:

TABLE 2. ORGANIZATION PROGRAM OF BANDUNG SMART CITY

\begin{tabular}{|c|c|c|c|}
\hline No & Working Program & No & Working Program \\
\hline 1 & $\begin{array}{l}\text { Bandung Command } \\
\text { Center }\end{array}$ & 14 & $\begin{array}{l}\text { The implementation of } \\
\text { knowledge management \& } \\
\text { system information in } \\
\text { government city of Bandung }\end{array}$ \\
\hline 2 & $\begin{array}{l}\text { Wi-Fi in Church and } \\
\text { Mosque }\end{array}$ & 15 & E-Proc 2.0 \\
\hline 3 & $\begin{array}{l}\text { Wi-Fi in the } \\
\text { government office }\end{array}$ & 16 & One chair one tablet \\
\hline 4 & $\begin{array}{l}\text { Wi-Fi in tourism } \\
\text { center }\end{array}$ & 17 & $\begin{array}{l}\text { ICT industry development } \\
\text { cluster }\end{array}$ \\
\hline 5 & $\begin{array}{l}\text { Wi-Fi in industrial } \\
\text { centers }\end{array}$ & 18 & Bandung Best Apps \\
\hline 6 & Wi-Fi in park & 19 & $\begin{array}{l}\text { Sabilulungan.Net (Social } \\
\text { assist \& grant Online) }\end{array}$ \\
\hline 7 & $\begin{array}{l}\text { Lapor (Citizen } \\
\text { Reporting) }\end{array}$ & 20 & $\begin{array}{l}\text { ICT technology using } \\
\text { training for Bandung city } \\
\text { official }\end{array}$ \\
\hline 8 & $\begin{array}{l}\text { Bandung smart card } \\
\text { (Angkot, bicycle, } \\
\text { etc.) }\end{array}$ & 21 & $\begin{array}{l}\text { ICT technology using } \\
\text { training for society }\end{array}$ \\
\hline 9 & $\begin{array}{l}\text { E-Parking prepaid } \\
\text { card }\end{array}$ & 23 & Ducting together \\
\hline 10 & $\begin{array}{l}\text { One agency one } \\
\text { social media account }\end{array}$ & 24 & $\begin{array}{l}\text { Re-Design Website } \\
\text { Government city of Bandung }\end{array}$ \\
\hline 11 & $\begin{array}{l}\text { Digitalizing the } \\
\text { documentation, } \\
\text { letters, disposition, } \\
\text { and agency's notes. }\end{array}$ & 25 & Enerbike for electricity \\
\hline 12 & Taxes Online & 26 & $\begin{array}{l}\text { Media campaign Bandung } \\
\text { Smart City }\end{array}$ \\
\hline 13 & $\begin{array}{l}\text { Bandung Techno } \\
\text { polis Gedebage }\end{array}$ & & \\
\hline
\end{tabular}

Source: Roadmap of Bandung victory, 2013 [7]

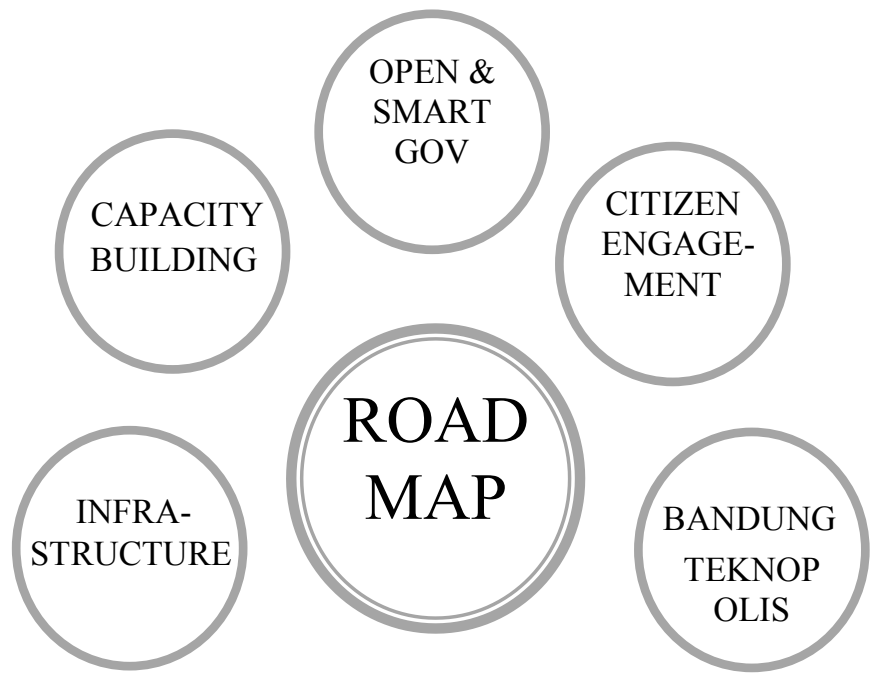

Source: Kamil, 2013 [6]

\section{Citizens' participation in Bandung smart city}

Empowerment of KHILAN in Palopo City is an activity done in a planned, comprehensive and involving various aspects that must be done in an integrated and well planned. In the empowerment activities are influenced by various factors both in supported and inhibit the process. The factors that affect the empowerment of KHILAN in Palopo City as follows.

Community participation in the Smart City underwent a transformation from a conventional wisdom be based on information technology. One of the components that play an important role is the existence of Bandung Command Center (BCC) under the communication and information Agency. The location of the BCC itself is located in the complex of Erect Bandung. Bandung Command Center (BCC) has two functions [8].

First, the function of the setting (control) and control (observe method). The function of the control and supervision is done for two objects namely surveillance of SKPD performance which is a structural unit under the mayor including officials also public deficits and oversight of the community especially the violators of the rule. Surveillance of SKPD (the agencies) is done through the monitoring of their performance. Monitoring is done through the integrated applications with the BCC. The applications that are in each SKPD can be displayed in the BCC with some authorization level. There is an application that can only be displayed (view) only and not has been intervened by BCC. For example for confidential data such as data tax revenues, the BCC is not given authority to $\log$ in and can only display only. But there are also some applications that were given authority to enter. In this case the corresponding SKPD provide username and password to the BCC so that it can be entered and seen how the application. The integration process this application to make it easier for the mayor of access the report or the progress of the work of certain SKPD without must come to the SKPD related. 
Thus the function of supervision and control can be done in a fast, easy and real time.

Second, the function as the center of the Data Center is directly related to the community service. The $\mathrm{BCC}$ function as a data center is directly related to the community service. There are three applications developed namely the Panic Button, Report, and Call Center 112.

The Panic Button that is the applications that directly made by the BCC for emergency services the city of Bandung. This application can be downloaded in the play store and App Store and then to be used when in a state of emergency such as citizens of the city suffered violence or become victims of crime. Using the application then will appear warning (alert) in the main screen control space BCC who told the officers that there are people who experience the following emergency position. The emergency report and then responded by sending the instructions to the police officer who in the vicinity of the sacrifice to immediately check and provide assistance. The application of Panic Button since the first launched have been downloaded by 2.036 user.

LAPOR! Application where this application developed by Ministry for the Empowerment of State Apparatus and Reformation Bureaucracy for the aspirations of complaints services online community. Bandung is 4 cities first to use the Passport service. This application launched 2013 until there is now around 10,000 user. And for incoming reports are about 10.949 report which almost $80 \%$ him already could be followed. With the existence of the application, BCC on duty to monitor, receive and forward a variety of complaints from the start complaints infrastructure problems, PPDB new student, etc. When there are complaints from the community and directly related to the provincial disposition to immediately followed up.

The existence of Smart City is enough help for ease and simplify working mechanism. Through Smart City, a report can be entered via the SMS, Twitter Facebook who then stay disposition and followed up. From the side of the follow-up can also more quickly and the community can monitor until assessed the process proconsuls; let them bring charges because they are given ID. In this way it can be said the community to actively participating in the government. Smart City alter the participation of the old model is now through the application to be more quickly and the community can play an active role in it. Only the weakness of the Smart City is the use of advanced ICT technology while the condition of the society is not entirely have the knowledge and the device support. In other words, participation is still limited because it is still a digital divide between the young generation and the old man. But this resolved with functioned Call Center 112 to bridge the parents are not yet IT literacy.

\section{CONCLUSION}

The implementation of smart city concept in managing urban areas become very important given the urban development that very quickly. Hard skill concept of Smart City can create a better public services, fast and responsive. This can be achieved by utilizing the progress of internet technology especially ICT. So far, technology implementation in a reign (city) proven to increase the efficiency in public policy and public service. Through e-government applications for example, made it easy for the government in implementing the various programs and policies. The use of technology through the concept of smart city also has been able to streamline and damaging the effectiveness of the management of urban areas and pressing the inefficiency of the budget. This condition can be achieved thanks to the ability of technology that is able to cut the bureaucracy that circular and eliminate KKN practices in the public service. Smart City also change the participation of the old model which is now through ICT applications that become more quickly and the community can play an active role in it. With Smart City then occurred simplification working mechanism and coordination across government agencies with the command is located in Bandung Command Center.

\section{ACKNOWLEDGMENT}

Thanks to the headship of university and the dean of social and political faculty, Padjadjaran University who has been giving assistance funding so that the opportunity to be able to carry out this research. Also thank you to the team of researchers have conducted research with very good.

\section{REFERENCES}

[1] A. Sodikin and R.A. Kusumaputra, "These are the cities of smart city recipient", retrieved from http://print.kompas.com/baca/iptek/2015/08/13/Inilah-Kota-KotaPenerima-Anugerah-Kota-Cerdas-201, August 2015.

[2] B. Cohen, "What exactly a smart city?", retrieved from http://www.boydcohen.com/smartcities.html.

[3] L. Moleong, "Qualitative Research Method" Bandung:Remaja Rosdakarya. 2002, p.32

[4] L. Mayangsari and S. Noviani, "Multi-stakeholders co-creation analysis in smart city management: an experience from Bandung, Indonesia" Procedia Manufacturing, Vol 4 (2015), pp. 315-321.

[5] Final Report Big Design Bandung Smart City, LAPI ITB, 2013. Unpublished.

[6] R. Kamil, tt. Smart City Bandung 2016.

[7] Roadmap to Bandung Juara, retrieved from https://portal.bandung.go.id/storage/media/daily/2016/12/27/znwXROadmap\%20to\%20Bandung\%20Juara\%20update\%2017_10_2013.pdf

[8] Profil Bandung Command Center, retreived from https://commandcenter.bandung.go.id/profil 